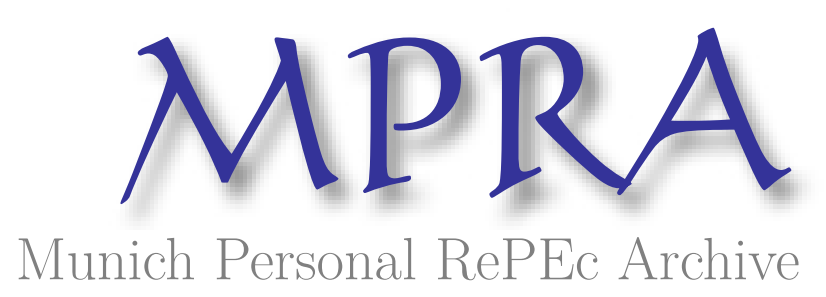

\title{
Health Disparities for Immigrants: Theory and Evidence from Canada
}

Lebihan, Laetitia and Mao Takongmo, Charles Olivier and McKellips, Fanny

University of Ottawa., University of Ottawa., University of Ottawa

13 June 2018

Online at https://mpra.ub.uni-muenchen.de/87375/

MPRA Paper No. 87375, posted 24 Aug 2018 10:15 UTC 


\title{
Health Disparities for Immigrants: Theory and Evidence from Canada*
}

\author{
Laetitia Lebihan $^{\dagger}$, C-O Mao Takongmo ${ }^{\ddagger}$ and Fanny McKellips ${ }^{\S}$ \\ University of Ottawa
}

June 13, 2018

\begin{abstract}
Few empirical studies have been conducted to analyse the disparities in health variables affecting immigrants in a given country. To our knowledge, no theoretical analysis has been conducted to explain health disparities for immigrants between regions in the same country that differs in term of languages spoken and income. In this paper, we use the Canadian Community Health Survey (CCHS) to compare multiple health measures among immigrants in Quebec, immigrants in the rest of Canada and Canadian-born individuals. We propose a simple structural model and conduct an empirical analysis in order to assess possible channels that can explain the health disparities for immigrants between two regions of the same country. Our results show that well-being and health indicators worsen significantly for immigrants in Quebec, compared to their counterparts in the rest of Canada and Canadian-born individuals. Additional econometric analysis also shows that life satisfaction is statistically and significantly associated with health outcomes. The proposed structural model predicts that, when the decision to migrate to a particular area is based on income alone, and if the fixed costs associated with the language barrier are large, immigrants may face health issues.
\end{abstract}

Keywords: immigrants, Canadian-born, well-being, health, Quebec.

JELL Classification: I14, I30, J10

*This paper has been previously circulated with the title "Health Inequalities for Immigrants in Canada: Quebec versus the Rest of Canada." We wish to thank Professor Jean-Marie Dufour, Professor Steven Ambler, Professor Victoria Zinde-Walsh, Professor Kristian Behrens, Professor Prosper Dovonon, and the editor for comments and suggestions.

${ }^{\dagger}$ University of Ottawa. Email: llebihan@uottawa.ca

‡Corresponding author, University of Ottawa, Email: cmaotako@uottawa.ca. Website: https://sites.google.com/site/maotakongmocharles

§University of Ottawa. Email: fmcke006@uottawa.ca 


\section{Introduction}

Considerable empirical research has been done to compare labour performance between immigrants who have settled in different regions of the same country. However, little has been done to analyze the disparities in health variables for immigrants in the same country. There is a substantial theoretical literature that analyses migration from one country to another, when the language barrier is taken into account. In our knowledge no theoretical analysis has been done analyzing the decision, and consequences on health, of migrating from one region to another in the same country, when the two regions differs from language and average income.

In this paper, we use the Canadian Community Health Survey (CCHS) to compare multiple health indicators among immigrants in Quebec, immigrants in the rest of Canada and Canadianborn individuals. In particular, we compare overall, mental and oral health; life satisfaction; drinking and smoking behaviors; hypertension and asthma; and obesity. We propose a simple structural model in order to explain health disparities for immigrants between regions. Additional econometric analysis also assess the link between life satisfaction and health variables.

The results from the first econometric analysis show that life satisfaction and overall, mental and oral health are significantly worse for immigrants in Quebec compared to their counterparts in the rest of Canada and Canadian-born individuals. Anxiety, mood disorders, binge drinking, smoking and obesity and overweight are more prevalent among immigrants in Quebec. We also observe that the likelihood of having a regular doctor is lower for immigrants in Quebec compared to their counterparts in the rest of Canada and Canadian-born individuals. Immigrants in Quebec consume fewer fruits and vegetables and are less likely to be house owners. Moreover, immigrants are less likely to report hypertension and cancer in Quebec, compared to those in the rest of Canada.

The proposed model provides a possible channels that can explain the health disparities for immigrants. The assumptions of the model are as follows. Agents can choose to migrate in one of the two regions of a given developed country. All regions apply the universal health system. The expected income for immigrants is different from one region to another. The official language in the two regions differs. Agent has to pay a fixed cost associated with the language barrier, if he chooses to migrate to a region with an official language that he does not speak. It is also assumed that health outcomes are functions of income. The model predicts that, if agents are short-sighted regarding their future health conditions, when taking their decisions, if the fixed cost associated with the language barrier is sufficiently large, compared to the difference between the expected income in the two regions, then agents will move to the region in which they do not have to pay the language fixed cost and the expected health outcomes for immigrants will be low.

In an additional econometric analysis, we assess the link between life satisfaction and health measures. Our investigation concludes that life satisfaction has a statistically significant impact on health variables. 
Many studies have focused on inequalities in the labour market between immigrants residing in Quebec and immigrants residing in the rest of Canada, as well as inequalities between immigrants and Canadian-born individuals (see, e.g., Boudarbat \& Connolly, 2013; Boulet \& Boudarbat 2015a). Such comparisons have not been made in terms of well-being and health indicators. Because health status is part of human capital, the human capital of immigrants residing in Quebec can be affected by health conditions. This situation may lead to economic inefficiencies in the future because of the health costs due to disease, and the low productivity of immigrants who are affected by those diseases. Good health status and high productivity for immigrants are important considerations in many migration policies around the world. As pointed out by Beiser (2005), in addition to economic considerations, it is humane to keep immigrants in good health. Comparing the health status of immigrants across different regions of the same country can help to reduce health inequalities and improve health conditions.

The paper is structured as follows. Section 2 briefly describes the health system in Canada. The data set used is presented in Section 3. Section 4 describes the methodology. The first econometric analysis is presented in Section 5. Section 6 present the structural model and additional econometric analysis of the link between life satisfaction and health outcomes. A short discussion is presented in section 7 and section 8 concludes the paper.

\section{Healthcare System in Canada and Healthcare Benefits for New Immigrants}

Canada's healthcare system, governed by the Canada Health Act, is publicly funded and administered by the provinces and territories. The Canada Health Act is based on five main principles: public administration, comprehensiveness, universality, portability and accessibility (Government of Canada, 1984). Through this act, all Canadians and permanent residents are entitled to universal coverage for insured services. The maximum waiting time for immigrants to receive a government health insurance card is three months for all provinces and territories. Emergency medical services are free for everyone in all provinces, even those who do not have a government health care card.

The final decision to make someone a permanent resident in Canada is taken by the federal government. Each candidate in the final process of becoming a permanent resident, as well as each member of his or her family, must take the Immigration Medical Exam (IME). The IME is performed by a doctor who is selected by the federal government, and the final decision to grant immigrant status is made after the government analyzes the medical certificate sent directly

by the doctor (Government of Canada, 2017). The medical examination includes a physical and mental examination; a review of medical history; a laboratory test; a diagnostic test; and a medical assessment of the applicant's records (Government of Canada 2002, Regulation 29). Therefore, regardless of the province to which the immigrant is preparing to move, each immigrant is subject 
to the same medical check.

The proportion of immigrants in the total population is increasing ${ }^{1}$ in Canada (Statistics Canada, 2011). According to Statistics Canada (2011), Quebec and Ontario are the provinces that received the largest number ${ }^{2}$ of new immigrants between 2006 and 2011. One natural interest of the Government of Canada and civil society is health inequalities among provinces for immigrants after arriving in Canada.

\section{Data}

We use micro-data from the Canadian Community Health Survey (CCHS), which is a crosssectional survey that collects information on the health status, health care utilization and health determinants of the Canadian population aged 12 or more (Statistics Canada, 2005). The survey started in 2001 and collected biennial samples for 2001, 2003 and 2005 and has collected yearly samples since 2007. Nevertheless, several variables have been constructed since 2003 and/or changed significantly after 2010. Therefore, we use the 2003-2010 period to ensure comparability over time. We focus on respondents aged 20 to 59 years because they are more likely to be in the labour market. The CCHS contains several indicators that are used in the literature to measure subjective well-being or behaviours related to health (Bradshaw et al., 2007; UNICEF Office of Research, 2013).

Using the CCHS, we examine several self-assessed health perceptions and subjective well-being indicators: (1) overall health; (2) mental health; (3) life satisfaction; and (4) oral health. In the CCHS, individuals rate their overall, mental and oral health as "poor", "fair", "good", "very good" or "excellent". Life satisfaction is measured using the question "How satisfied are you with your life in general?" Respondents choose from five options, ranging from "very dissatisfied" to "very satisfied." Several indicators assess the presence of (5) hypertension, (6) asthma, (7) diabetes, (8) heart disease and (9) cancer. Respondents are asked whether they have (10) anxiety disorders (such as phobias, obsessive-compulsive disorder or a panic disorder), (11) mood disorders (such as depression, bipolar disorder, mania or dysthymia) and (12) a regular medical doctor. They also report whether they (13) drink "not at all," "occasionally" or "regularly," as well as their prevalence of (14) binge drinking, which is defined as having five or more drinks in one sitting (Flegel et al., 2011). We also observe whether (15) they smoke "not at all," "occasionally" or "daily." Moreover, respondents rate their (16) fruit and vegetable consumption per day. Body mass index is calculated from self-reported height and weight, and respondents are classified if

\footnotetext{
${ }^{1}$ The immigrant population increased from $17.2 \%$ of the total population in Canada in 2006 to $20.6 \%$ of the total population in 2011 (Statistics Canada 2011). According to Statistics Canada (2011), 94.8\% of immigrants live in Ontario, British Columbia, Quebec and Alberta. Of those immigrants, $53.3 \%$ live in Ontario, $17.6 \%$ in British Columbia, $14.4 \%$ in Quebec and $9.5 \%$ in Alberta.

${ }^{2}$ In that period, $43.1 \%$ of new immigrants was received in Ontario, $19.2 \%$ in Quebec and $15.9 \%$ in British Columbia (see Statistics Canada, 2011)
} 
they are (17) overweight or obese. Respondents also report whether they (18) engage in physical activity of more than 15 minutes per day and whether they are (19) house owners. Appendix Table A.1 provides details on each measure.

The controls used in the regressions with CCHS data are the sex of the respondent; dummies for the highest level of education of the respondent -less than a high school diploma, high school diploma, other post-secondary education, with a post secondary diploma; dummies for the age of the respondent; dummies for the marital status of the respondent - married/commonlaw, single/never married, widowed/separated/divorced; dummies for the size of the respondent's household - from 1 to 5 or more; dummies for the language the respondent can speak - English, French, English and French, neither; and, finally, dummies for years. Summary statistics for Quebec and for the rest of Canada for immigrants and Canadian-born individuals are presented in Appendix Table A.2.

\section{Empirical strategy}

For each well-being and health indicator, we estimate the following model:

$$
Y_{i t}=\alpha+\beta_{1} \text { Que }_{i t}+\beta_{2} I m m_{i t}+\beta_{3} Q u e_{i t} \times I m m_{i t}+\beta_{4} X_{i t}+\varepsilon_{i t}
$$

where $Y_{i t}$ represents the well-being/health indicator considered for respondent $i$ in wave $t$. The term $Q u e_{i t}$ is a dummy variable taking the value of 1 if the respondent lives in Quebec in wave $t$ and 0 otherwise. The term $I m m_{i t}$ equals one if the respondent was not born in Canada (immigrant) and 0 otherwise. The term $Q u e_{i t} \times I m m_{i t}$ equals 1 if the respondent resides in Quebec and is an immigrant; it is 0 otherwise. Finally, the term $X_{i t}$ is a vector of socioeconomic control variables, and $\varepsilon_{i t}$ is an error term.

If $\beta_{1}$ is statistically significant, respondents living in Quebec differ from those in other Canadian provinces for the measure studied. Similarly, if $\beta_{2}$ is statistically significant, immigrants differ from those born in Canada. Finally, if $\beta_{3}$ is statistically significant, immigrants in Quebec differ from immigrants in other Canadian provinces and Canadian-born individuals in Canada overall.

For dichotomous variables (e.g., hypertension), we estimate probit regressions (marginal effects are presented); for those with more than two categories (e.g., overall health), we use ordered probit regressions. For continuous variables (e.g., fruit and vegetable consumption), we estimate linear regressions via ordinary least squares. All statistical analyses are weighted using sample weights from Statistics Canada. We also report the direction of each measure for which the independent variable has a beneficial effect on the respondent. 


\section{$5 \quad$ Results}

Table 1 presents the estimates of the above model. We show that Quebec residents have better life satisfaction and overall, mental and oral health compared to their counterparts in the rest of Canada. However, for these same variables, immigrants, regardless of geography, are in poorer health than Canadian-born individuals. This is surprising because several studies show that immigrants are healthier than the Canadian-born as a result of the immigration selection process. However, when stratifying by length of stay in Canada (results available on demand), we found that only immigrants who have been in the country for 10 years or more are less healthy than the Canadian-born; the effect is zero for immigrants who have been in the country for 0-9 years. This confirms the healthy immigrant effect hypothesis, according to which recent immigrants are healthier than their Canadian-born counterparts but experience a decrease in this health status advantage over time (Gee et al., 2004; De Maio et al., 2010). In Table 1, we also show that life satisfaction and overall, mental and oral health worsen significantly for immigrants in Quebec compared to their counterparts in the rest of Canada and Canadian-born individuals.

We found no statistically significant differences between immigrants in Quebec and their counterparts in the rest of Canada and Canadian-born individuals in the likelihood of developing asthma, diabetes or heart disease (Table 1). For hypertension and cancer, immigrants in Quebec are less likely to report these diseases, but the effects are very small (decreased by 1 percentage point and 0.1 percentage point, respectively). Table 1 also shows that anxiety and mood disorders are more prevalent among immigrants in Quebec despite the small size of the effects (between 1.1 and 1.9 percentage point). Living in Quebec decreases the likelihood of having a regular doctor by 15.6 percentage points. This is not surprising because several studies have showed difficulty in access to health care in Quebec, in particular for having a family doctor (CIHI, 2016). For immigrants in Quebec, the likelihood of having a regular doctor also decreases.

For drinking, we found no statistically significant difference between immigrants in Quebec and their counterparts in the rest of Canada. However, immigrants in Quebec are more likely to engage in binge drinking and, smoking. We also show that immigrants in Quebec consume less fruits and vegetables on average and are more likely to become overweight or obese. However, there is no statistically significant difference between immigrants in Quebec and their counterparts in the rest of Canada for physical activity. Finally, immigrants in Quebec are less likely to own a house.

Table 2 shows the estimated effects for Quebec and Ontario only, by the sex of the respondent and by length of time in Canada since immigration. We first present the results comparing Quebec and Ontario. We show that the results remain similar. Clearly, several well-being and health indicators worsen significantly for immigrants in Quebec compared to their counterparts in the rest of Canada and Canadian-born individuals.

When stratifying by the sex of respondent, we show that female and male immigrants in Quebec are both affected, but men are more affected in terms of mental health. 
We also stratify by length of time in Canada since immigration: 0-9 years and 10 years and more. We show that negative effects on health and well-being are more pronounced for immigrants who have been in Quebec for 10 years and more than for those who have recently immigrated to Quebec. This is not surprising because several studies have showed the healthy immigrant effect in Canada (Wang et al., 2017).

In sum, it appears that well-being and health indicators worsen significantly for immigrants in Quebec compared to their counterparts in the rest of Canada and Canadian-born individuals. This is particularly true for mental health and life satisfaction. 
Table 1: Probit, ordered and linear regression estimates for the full sample.

\begin{tabular}{|c|c|c|c|c|}
\hline Variables & Model & Quebec & Immigrant & Quebec*Immigrant \\
\hline \multirow[t]{2}{*}{ Overall health $(+)$} & Ordered probit regression & $0.066^{* * *}$ & $-0.046^{* * *}$ & $-0.104^{* * *}$ \\
\hline & $\mathrm{N}=282,410$ & $(0.025)$ & $(0.015)$ & $(0.017)$ \\
\hline \multirow{2}{*}{ Mental health $(+)$} & Ordered probit regression & $0.119^{* * *}$ & -0.018 & $-0.107 * * *$ \\
\hline & $\mathrm{N}=279,615$ & $(0.022)$ & $(0.015)$ & $(0.014)$ \\
\hline \multirow[t]{2}{*}{ Life satisfaction $(+)$} & Ordered probit regression & $0.024^{* *}$ & $-0.245^{* * *}$ & $-0.101^{* * *}$ \\
\hline & $\mathrm{N}=279,195$ & $(0.012)$ & $(0.026)$ & $(0.025)$ \\
\hline \multirow[t]{2}{*}{ Oral health $(+)$} & Ordered probit regression & $0.034^{* * *}$ & $-0.188^{* * *}$ & $-0.191^{* * *}$ \\
\hline & $\mathrm{N}=141,902$ & $(0.012)$ & $(0.036)$ & $(0.0323)$ \\
\hline \multirow[t]{2}{*}{ Hypertension (-) } & Probit regression & -0.006 & 0.001 & $-0.010^{* *}$ \\
\hline & $\mathrm{N}=281,908$ & $(0.004)$ & $(0.005)$ & $(0.004)$ \\
\hline \multirow[t]{2}{*}{ Asthma (-) } & Probit regression & $-0.006^{*}$ & $-0.040^{* * *}$ & 0.001 \\
\hline & $\mathrm{N}=282,423$ & $(0.004)$ & $(0.003)$ & $(0.004)$ \\
\hline \multirow[t]{2}{*}{ Diabete (-) } & Probit regression & -0.002 & $0.007^{* *}$ & 0.002 \\
\hline & $\mathrm{N}=282,376$ & $(0.002)$ & $(0.004)$ & $(0.003)$ \\
\hline \multirow[t]{2}{*}{ Heart disease (-) } & Probit regression & $0.002^{*}$ & -0.003 & -0.001 \\
\hline & $\mathrm{N}=282,247$ & $(0.001)$ & $(0.002)$ & $(0.002)$ \\
\hline \multirow[t]{2}{*}{ Cancer (-) } & Probit regression & $-0.002^{*}$ & $-0.002^{* * *}$ & $-0.001^{* *}$ \\
\hline & $\mathrm{N}=282,344$ & $(0.001)$ & $(0.001)$ & $(0.001)$ \\
\hline \multirow[t]{2}{*}{ Anxiety disorders (-) } & Probit regression & $-0.010^{* * *}$ & $-0.027^{* * *}$ & $0.011^{* * *}$ \\
\hline & $\mathrm{N}=282,294$ & $(0.002)$ & $(0.002)$ & $(0.003)$ \\
\hline \multirow[t]{2}{*}{ Mood disorders (-) } & Probit regression & $-0.026^{* * *}$ & $-0.027^{* * *}$ & $0.019^{* * *}$ \\
\hline & $\mathrm{N}=282,337$ & $(0.002)$ & $(0.003)$ & $(0.003)$ \\
\hline \multirow[t]{2}{*}{ Regular medical doctor $(+)$} & Probit regression & $-0.156^{* * *}$ & $-0.015^{* * *}$ & $-0.084^{* * *}$ \\
\hline & $\mathrm{N}=282,449$ & $(0.012)$ & $(0.005)$ & $(0.012)$ \\
\hline \multirow[t]{2}{*}{ Drinking- type of drinking (-) } & Ordered probit regression & $0.142^{* * *}$ & $-0.548^{* * *}$ & -0.041 \\
\hline & $\mathrm{N}=281,769$ & $(0.041)$ & $(0.041)$ & $(0.043)$ \\
\hline \multirow[t]{2}{*}{ Drinking- binge drinking (-) } & Probit regression & $-0.017^{* * *}$ & $-0.118^{* * *}$ & $0.014^{* * *}$ \\
\hline & $\mathrm{N}=237,642$ & $(0.006)$ & $(0.004)$ & $(0.004)$ \\
\hline \multirow[t]{2}{*}{ Smoking (-) } & Ordered probit regression & $0.098^{* * *}$ & $-0.531^{* * *}$ & $0.064^{* * *}$ \\
\hline & $\mathrm{N}=282,255$ & $(0.020)$ & $(0.007)$ & $(0.011)$ \\
\hline \multirow{2}{*}{$\begin{array}{l}\text { Fruit and vegetable } \\
\text { consumption }(+)\end{array}$} & Linear regression & $0.314^{* * *}$ & $0.140^{*}$ & $-0.375^{* * *}$ \\
\hline & $\mathrm{N}=240,598$ & $(0.053)$ & $(0.063)$ & $(0.064)$ \\
\hline \multirow[t]{2}{*}{ Obesity and overweight (-) } & Probit regression & $-0.056^{* * *}$ & $-0.122^{* * *}$ & $0.099^{* * *}$ \\
\hline & $\mathrm{N}=270,686$ & $(0.013)$ & $(0.018)$ & $(0.017)$ \\
\hline \multirow[t]{2}{*}{ Physical activity $(+)$} & $\mathrm{N}=$ Probit regression & $-0.096^{* * *}$ & $-0.072^{* * *}$ & 0.030 \\
\hline & $\mathrm{N}=279,666$ & $(0.013)$ & $(0.017)$ & $(0.019)$ \\
\hline \multirow[t]{2}{*}{ Home ownership $(+)$} & Probit regression & $-0.073^{* * *}$ & $-0.131^{* * *}$ & $-0.101^{* * *}$ \\
\hline & $\mathrm{N}=281,803$ & $(0.014)$ & $(0.013)$ & $(0.017)$ \\
\hline
\end{tabular}

Notes: Standard errors are clustered by province (reported in parentheses). All estimates are weighted. We also report the direction of each indicators for which the variable has a beneficial effect on the respondent. $* * *$ : significant at $1 \% ; * *$ : significant at $5 \% ; *$ : significant at $10 \%$ 
Table 2: Probit, ordered and linear regression estimates for several sub-samples.

\begin{tabular}{|c|c|c|c|c|c|c|c|c|c|c|}
\hline \multirow[b]{3}{*}{ VARIABLES } & \multirow{2}{*}{\multicolumn{2}{|c|}{$\begin{array}{c}\text { Quebec vs Ontario } \\
\text { Only Ontario }\end{array}$}} & \multicolumn{4}{|c|}{ Gender } & \multicolumn{4}{|c|}{ Length of time in Canada since immigration } \\
\hline & & & \multicolumn{2}{|c|}{ Male } & \multicolumn{2}{|c|}{ Female } & \multicolumn{2}{|c|}{$0-9$ years } & \multicolumn{2}{|c|}{10 years and more } \\
\hline & Que*Imm & $\mathrm{N}$ & Que*Imm & $\mathrm{N}$ & Que*Imm & $\mathrm{N}$ & Que*Imm & $\mathrm{N}$ & Que*Imm & $\mathrm{N}$ \\
\hline Overall health $(+)$ & $\begin{array}{c}-0.085^{* * *} \\
(0.031)\end{array}$ & 151,320 & $\begin{array}{c}-0.120 * * * \\
(0.018)\end{array}$ & 130,927 & $\begin{array}{c}-0.095 * * * \\
(0.016)\end{array}$ & 151,483 & $\begin{array}{c}-0.052 * * \\
(0.025)\end{array}$ & 256,031 & $\begin{array}{c}-0.138^{* * *} \\
(0.015)\end{array}$ & 271,352 \\
\hline Mental health $(+)$ & $\begin{array}{c}-0.083^{* * *} \\
(0.030)\end{array}$ & 149,954 & $\begin{array}{c}-0.124 * * * \\
(0.014)\end{array}$ & 129,136 & $\begin{array}{c}-0.094^{* * *} \\
(0.015)\end{array}$ & 150,479 & $\begin{array}{c}-0.099 * * * \\
(0.024)\end{array}$ & 253,587 & $\begin{array}{c}-0.114^{* * *} \\
(0.012)\end{array}$ & 268,779 \\
\hline Life satisfaction $(+)$ & $\begin{array}{c}-0.070^{* *} \\
(0.030)\end{array}$ & 149,739 & $\begin{array}{c}-0.122^{* * *} \\
(0.034)\end{array}$ & 128,905 & $\begin{array}{c}-0.0820^{* * *} \\
(0.017)\end{array}$ & 150,290 & $\begin{array}{c}-0.062 \\
(0.049)\end{array}$ & 253,244 & $\begin{array}{c}-0.099^{* * *} \\
(0.016)\end{array}$ & 268,402 \\
\hline Oral health $(+)$ & $\begin{array}{c}-0.138^{* * *} \\
(0.043)\end{array}$ & 75,291 & $\begin{array}{c}-0.208^{* * *} \\
(0.050)\end{array}$ & 65,461 & $\begin{array}{c}-0.185^{* * *} \\
(0.017)\end{array}$ & 76,441 & $\begin{array}{c}-0.086 * * \\
(0.036)\end{array}$ & 128,720 & $\begin{array}{c}-0.232 * * * \\
(0.033)\end{array}$ & 136,802 \\
\hline Hypertension (-) & $\begin{array}{c}-0.014^{*} \\
(0.008)\end{array}$ & 151,092 & $\begin{array}{c}-0.009 * * \\
(0.005)\end{array}$ & 130,533 & $\begin{array}{c}-0.010^{* * *} \\
(0.004)\end{array}$ & 151,375 & $\begin{array}{c}-0.023^{* * *} \\
(0.006)\end{array}$ & 255,559 & $\begin{array}{l}-0.004 \\
(0.004)\end{array}$ & 270,860 \\
\hline Asthma (-) & $\begin{array}{c}0.007 \\
(0.009)\end{array}$ & 151,325 & $\begin{array}{c}0.004 \\
(0.005)\end{array}$ & 130,936 & $\begin{array}{l}-0.003 \\
(0.004)\end{array}$ & 151,487 & $\begin{array}{c}0.002 \\
(0.008)\end{array}$ & 256,026 & $\begin{array}{c}0.005 \\
(0.003)\end{array}$ & 271,370 \\
\hline Diabete (-) & $\begin{array}{l}-0.002 \\
(0.005)\end{array}$ & 151,279 & $\begin{array}{c}-0.008 * * \\
(0.004)\end{array}$ & 130,914 & $\begin{array}{c}0.014 * * * \\
(0.003)\end{array}$ & 151,462 & $\begin{array}{c}-0.012^{* * *} \\
(0.002)\end{array}$ & 255,988 & $\begin{array}{c}0.001 * * \\
(0.003)\end{array}$ & 271,323 \\
\hline Heart disease (-) & $\begin{array}{l}-0.003 \\
(0.005)\end{array}$ & 151,240 & $\begin{array}{c}-0.003 * \\
(0.002)\end{array}$ & 130,847 & $\begin{array}{c}0.002 \\
(0.002)\end{array}$ & 151,400 & $\begin{array}{c}-0.006 * * * \\
(0.001)\end{array}$ & 255,881 & $\begin{array}{c}0.001 \\
(0.002)\end{array}$ & 271,194 \\
\hline Cancer (-) & $\begin{array}{l}-0.001 \\
(0.003)\end{array}$ & 151,257 & $\begin{array}{c}0.002 * * \\
(0.001)\end{array}$ & 130,916 & $\begin{array}{c}-0.004^{* * *} \\
(0.001)\end{array}$ & 151,428 & $\begin{array}{c}-0.001 \\
(0.002)\end{array}$ & 255,958 & $\begin{array}{c}-0.001^{* * *} \\
(0.000)\end{array}$ & 271,287 \\
\hline Anxiety disorders (-) & $\begin{array}{c}0.014^{*} \\
(0.008)\end{array}$ & 151,258 & $\begin{array}{c}0.007^{*} \\
(0.004)\end{array}$ & 130,877 & $\begin{array}{c}0.014^{* * *} \\
(0.002)\end{array}$ & 151,417 & $\begin{array}{c}0.028^{* * *} \\
(0.004)\end{array}$ & 255,928 & $\begin{array}{c}0.011^{* * *} \\
(0.003)\end{array}$ & 271,260 \\
\hline Mood disorders (-) & $\begin{array}{c}0.017^{* *} \\
(0.009)\end{array}$ & 151,275 & $\begin{array}{c}0.013^{* * *} \\
(0.001)\end{array}$ & 130,875 & $\begin{array}{c}0.024^{* * *} \\
(0.004)\end{array}$ & 151,462 & $\begin{array}{c}0.031 * * * \\
(0.005)\end{array}$ & 255,959 & $\begin{array}{c}0.018 * * * \\
(0.003)\end{array}$ & 271,291 \\
\hline Regular medical doctor $(+)$ & $\begin{array}{c}-0.072^{* * *} \\
(0.011)\end{array}$ & 151,334 & $\begin{array}{c}-0.100^{* * *} \\
(0.022)\end{array}$ & 130,920 & $\begin{array}{c}-0.069 * * * \\
(0.010)\end{array}$ & 151,529 & $\begin{array}{c}-0.106 * * * \\
(0.012)\end{array}$ & 256,051 & $\begin{array}{c}-0.062 * * * \\
(0.012)\end{array}$ & 271,387 \\
\hline Drinking- type of drinking (-) & $\begin{array}{c}0.029 \\
(0.035)\end{array}$ & 151,096 & $\begin{array}{l}-0.064 \\
(0.048)\end{array}$ & 130,591 & $\begin{array}{l}-0.018 \\
(0.0380)\end{array}$ & 151,178 & $\begin{array}{l}-0.013 \\
(0.087)\end{array}$ & 255,440 & $\begin{array}{c}0.011 \\
(0.030)\end{array}$ & 270,735 \\
\hline Drinking- binge drinking (-) & $\begin{array}{c}0.014 \\
(0.015)\end{array}$ & 128,741 & $\begin{array}{c}0.022^{* * * *} \\
(0.005)\end{array}$ & 113,593 & $\begin{array}{c}0.007^{*} \\
(0.004)\end{array}$ & 124,049 & $\begin{array}{c}0.054^{* * *} \\
(0.0120)\end{array}$ & 217,534 & $\begin{array}{c}0.004 \\
(0.003)\end{array}$ & 230,830 \\
\hline Smoking (-) & $\begin{array}{l}0.061^{*} \\
(0.032)\end{array}$ & 151,275 & $\begin{array}{c}0.052^{* * *} \\
(0.015)\end{array}$ & 130,837 & $\begin{array}{c}0.066^{* * *} \\
(0.011)\end{array}$ & 151,418 & $\begin{array}{c}0.125^{* * *} \\
(0.009)\end{array}$ & 255,883 & $\begin{array}{c}0.054^{* * *} \\
(0.014)\end{array}$ & 271,198 \\
\hline $\begin{array}{l}\text { Fruit and vegetable } \\
\text { consumption }(+)\end{array}$ & $\begin{array}{c}-0.364^{* *} \\
(0.019)\end{array}$ & 130,375 & $\begin{array}{c}-0.257 * * * \\
(0.060)\end{array}$ & 110,783 & $\begin{array}{c}-0.516 * * * \\
(0.072)\end{array}$ & 129,815 & $\begin{array}{c}-0.253 * * * \\
(0.073)\end{array}$ & 216,783 & $\begin{array}{c}-0.443 * * * \\
(0.060)\end{array}$ & 230,952 \\
\hline Obesity and overweight (-) & $\begin{array}{c}0.075^{* * *} \\
(0.013)\end{array}$ & 145,633 & $\begin{array}{c}0.103^{* * *} \\
(0.012)\end{array}$ & 129,292 & $\begin{array}{c}0.091^{* * *} \\
(0.022)\end{array}$ & 141,394 & $\begin{array}{c}0.095^{* * *} \\
(0.014)\end{array}$ & 245,273 & $\begin{array}{c}0.112^{* * *} \\
(0.018)\end{array}$ & 260,363 \\
\hline Physical activity $(+)$ & $\begin{array}{c}0.056^{* * *} \\
(0.014)\end{array}$ & 150,035 & $\begin{array}{c}0.010 \\
(0.020)\end{array}$ & 129,151 & $\begin{array}{c}0.052^{* * *} \\
(0.020)\end{array}$ & 150,515 & $\begin{array}{c}0.034 \\
(0.022)\end{array}$ & 253,627 & $\begin{array}{c}0.034^{*} \\
(0.019)\end{array}$ & 268,841 \\
\hline Home ownership $(+)$ & $\begin{array}{c}-0.085^{* * *} \\
(0.012)\end{array}$ & 151,117 & $\begin{array}{c}-0.126 * * * \\
(0.016)\end{array}$ & 130,653 & $\begin{array}{c}-0.072 * * * \\
(0.017)\end{array}$ & 151,150 & $\begin{array}{c}-0.133 * * * \\
(0.019)\end{array}$ & 255,508 & $\begin{array}{c}-0.069 * * * \\
(0.018)\end{array}$ & 270,799 \\
\hline
\end{tabular}

Notes: Standard errors are clustered by province (reported in parentheses). All estimates are weighted. We also report the direction of each indicator for which the variable has a beneficial effect on the respondent. Statistically different estimates between males and females and between $0-9$ years and 10 years or more are presented in bold face.

***: significant at $1 \% ; * *$ : significant at $5 \% ;^{*}$ : significant at $10 \%$ 


\section{The model}

The model presented in this paragraph helps to analyse the decision and the consequences of that decision on health, for an agent who is allowed to move from a developing country to a developed country, but who has the choice to migrate in one of two regions of a given developed country.

In one region of the developed country, the official language is similar to the native language of the immigrant. In the second region, the language spoken is significantly different. We assume that agent will face a direct language fixed cost if he decides to migrate to the region with an official language that is different from his native language. We assume that both regions of the developed country are served by the universal health system. We also assume that health outcomes are functions of income.

The predictions of the model are as follows. If agents are short-sighted regarding their future health conditions, when taking their decisions, if the fixed cost associated with the language barrier is sufficiently large, compared to the differences between expected income in the two regions, then agents will choose to migrate to the region with an official language similar to their native language. The model also predicts that the average health outcomes for immigrants will be lower.

The model is describe as follows. There are two countries: a Poor country, $\mathbb{P}$, and a Rich country, $\mathbb{R}$. Country $\mathbb{R}$ is divided into two regions: without lost of generalities, one in which people speak French, labeled F, and one in which people speak English, labeled E. For simplicity we assume that people in the poor country, $\mathbb{P}$, speak French only.

A proportion of people who live in the poor country $\mathbb{P}$, are allowed to migrate to the rich country. Individuals who are allowed to migrate to the rich country are free to choose between two regions. In the first region, the official language is French, $\mathbb{R F}$. In the second region, the official language is English, $\mathbb{R E}$.

There is a cost associated with migrating in the region with English as the official language, $\mathbb{R E}$, ( for example the number of years necessary to learn English, or the direct social cost of living in a region with no knowledge of the official language).

For simplicity, there are only two possible salaries for each individual i, $Y_{i}^{+}$and $Y_{i}^{-}$with $\left(Y_{i}^{+}>Y_{i}^{-}\right)$. In the region where French is the official language, $\mathbb{R F}$, each worker will have either a high-pay job (job that pays $Y_{i}^{+}$) with probability $P_{F, i}$ or a low pay job (that pays $Y_{i}^{-}$) with probability $1-P_{F, i}$.

In the region where English is the first language, $\mathbb{R E}$, the probability for worker i to have a high pay job is $P_{E, i}$ and the probability of having a low pay job is $1-P_{E, i}$. As in the French-speaking region, a high pay job also pays $Y_{i}^{+}$and a low pay job pays $Y_{i}^{-}$.

We assume that an individual $\mathrm{i}$ is allowed to migrate from the poor country, $\mathbb{P}$, to the rich country, $\mathbb{R}$. Our interest is to analyse the decision of agent $i$ to move to the region $\mathbb{R F}$ compared to region $\mathbb{R E}$ and the consequences of this decision on the agent's health outcomes.

The decision to migrate to region $\mathbb{R F}$, as compared to region $\mathbb{R E}$, is based on expected future 
income and expected health conditions.

The expected utility function of individual i at period 0 (before moving to the rich country) for migrating to the region with French as the official language $\mathbb{R F}$, is

$$
E_{0}\left(U_{F}\right)=\sum_{t=1}^{\infty} \beta^{t} \frac{\left\{\left(\frac{E_{F, 0}\left[Y_{i t}\right]-Y_{i}^{-}}{Y_{i}^{+}-Y_{i}^{-}}\right)^{\alpha}\left(\frac{E_{F, 0}\left[H_{i t}\right]-H_{i}^{-}}{H_{i}^{+}-H_{i}^{-}}\right)^{1-\alpha}\right\}^{1-\sigma}-1}{1-\sigma},
$$

where

$$
E_{F, 0}\left[Y_{i t}\right]=\left(1-P_{F, i}\right) Y_{i}^{-}+P_{F, i} Y_{i}^{+}
$$

$\frac{E_{F, 0}\left[Y_{i t}\right]-Y_{i}^{-}}{Y_{i}^{+}-Y_{i}^{-}}$indicates how far the expected income is from the minimum value. $E_{F, 0}\left[Y_{i t}\right]-Y_{i}^{-}$ is divided by $Y_{i}^{+}-Y_{i}^{-}$in other to have an index that belongs to the real space, especially between 0 and 1.

The expected health outcome is also normalized, for the same reason. $\frac{E_{F, 0}\left[H_{i t}\right]-H_{i}^{-}}{H_{i}^{+}-H_{i}^{-}}$will also be a real number between 0 and 1 . The greater value for this index, the better it is.

The expected utility function of individual i at period 0 (before moving to the rich country) for migrating to the region with English as the official language $\mathbb{R} \mathbb{E}$, is

$$
E_{0}\left(U_{E}\right)=\sum_{t=1}^{\infty} \beta^{t} \frac{\left\{\left(\frac{E_{E, 0}\left[Y_{i t}\right]-Y_{i}^{-}}{Y_{i}^{+}-Y_{i}^{-}}\right)^{\alpha}\left(\frac{E_{E, 0}\left[H_{i t}\right]-H_{i}^{-}}{H_{i}^{+}-H_{i}^{-}}\right)^{1-\alpha}\right\}^{1-\sigma}-1}{1-\sigma}-\text { DirectLCost }
$$

where DirectLCost is a direct language fixed cost related to lack of proficiency in English, such as the cost of learning English, or social costs, when English is the official language.

$$
E_{E, 0}\left[Y_{i t}\right]=\left(1-P_{E, i}\right) Y_{i}^{-}+P_{E, i} Y_{i}^{+}
$$

\section{The decision of agent $\mathrm{i}$ can be summarized as follow:}

- Agent $\mathrm{i}$ will choose to migrate to the region where French is the official language if $E_{0}\left(U_{F}\right)>$ $E_{0}\left(U_{E}\right)$.

- Agent $\mathrm{i}$ will choose to migrate to the region where English is the official language if $E_{0}\left(U_{F}\right)<$ $E_{0}\left(U_{E}\right)$.

- Agent $\mathrm{i}$ will be indifferent to migrating in one region or another if $E_{0}\left(U_{F}\right)=E_{0}\left(U_{E}\right)$.

\subsection{The health function}

In this model, in both regions of the developed country, health outcomes are assumed to be a function of the gap between observed income and minimum income. Health may also be affected 
by a random event that can either damage or improve health conditions. The health function for the two regions is defined by

$$
H_{i t}=H_{i t}\left(Y_{i t}, \eta_{i t}\right)=\frac{Y_{i t}-Y_{i}^{-}}{Y_{i}^{+}-Y_{i}^{-}}+\frac{\eta_{i t}-\eta_{\min }}{\eta_{\max }-\eta_{\min }},
$$

where $\eta_{i t}$ is a random variable that represents all factors that may affect health and that cannot be explained by the distance between the observed income and the minimum income. $\eta_{\min }$ is the worst negative impact on health and $\eta_{\max }$ is the best positive impact on health.

We assume that $\eta_{i t}$ is a realization from the uniform distribution with support $\left[\begin{array}{ll}\eta_{\min } & \eta_{\max }\end{array}\right]=$ $\left[\begin{array}{ll}-1 & 1\end{array}\right]$. A negative realization of $\eta_{i t}$ will have a negative effect on the agent's health, and a positive realization of $\eta_{i t}$ will have a positive effect on health.

Condition 1:

$$
(1-\sigma)(1-\beta) \text { DirectLCost }>\left(\frac{E_{E, 0}\left[Y_{i t}\right]-Y_{i}^{-}}{Y_{i}^{+}-Y_{i}^{-}}\right)^{1-\sigma}-\left(\frac{E_{F, 0}\left[Y_{i t}\right]-Y_{i}^{-}}{Y_{i}^{+}-Y_{i}^{-}}\right)^{1-\sigma}>0
$$

Condition 1 considers the case in which the direct cost of lack of proficiency in English is very high, compare to an indicator of disparity between the expected income for an immigrant between the two regions.

Theorem 1. Assume that income is stationary in both regions of the country.

If condition 1 is satisfied, if, in addition to that, agents do not take into account health issues when taking their decision to move (i.e. $\alpha=1$ ), then:

- immigrants will move to the region where French is the official language and,

- the expected health conditions for immigrants in the region where French is the official language will be lower than their expected health conditions in the alternative region (where English is the official language). That is

$$
E_{E, 0}\left[H_{E i t}\right]-E_{F, 0}\left[H_{F i t}\right]>0
$$

Proof.

$$
E_{0}\left(U_{F}\right)=\sum_{t=1}^{\infty} \beta^{t} \frac{\left\{\left(\frac{E_{F, 0}\left[Y_{i t}\right]-Y_{i}^{-}}{Y_{i}^{+}-Y_{i}^{-}}\right)^{\alpha}\left(\frac{E_{F, 0}\left[H_{i t}\right]-H_{i}^{-}}{H_{i}^{+}-H_{i}^{-}}\right)^{1-\alpha}\right\}^{1-\sigma}-1}{1-\sigma},
$$

If income is stationary, then the expected income will not depend on time. Moreover, if agents do not take into account health issues when taking their decision to move (i.e. $\alpha=1$ ), the expected utility function for moving in the French region will become

$$
E_{0}\left(U_{F}\right)=\frac{\left(\frac{E_{F, 0}\left[Y_{i t}\right]-Y_{i}^{-}}{Y_{i}^{+}-Y_{i}^{-}}\right)^{1-\sigma}-1}{(1-\sigma)(1-\beta)} \text { and the corresponding expected utility function for moving to }
$$
the English region will becomes $E_{0}\left(U_{E}\right)=\frac{\left(\frac{E_{E, 0}\left[Y_{i t}\right]-Y_{i}^{-}}{Y_{i}^{+}-Y_{i}^{-}}\right)^{1-\sigma}-1}{(1-\sigma)(1-\beta)}-$ DirectLCost and 


$$
\begin{aligned}
E_{0}\left(U_{F}\right)-E_{0}\left(U_{E}\right) & =\frac{\left(\frac{E_{F, 0}\left[Y_{i t}\right]-Y_{i}^{-}}{Y_{i}^{+}-Y_{i}^{-}}\right)^{1-\sigma}-1}{(1-\sigma)(1-\beta)}-\left\{\frac{\left(\frac{E_{E, 0}\left[Y_{i t}\right]-Y_{i}^{-}}{Y_{i}^{+}-Y_{i}^{-}}\right)^{1-\sigma}-1}{(1-\sigma)(1-\beta)}-\text { DirectLCost }\right\} \\
& =\frac{\left(\frac{E_{F, 0}\left[Y_{i t}\right]-Y_{i}^{-}}{Y_{i}^{+}-Y_{i}^{-}}\right)^{1-\sigma}-1}{(1-\sigma)(1-\beta)}-\frac{\left(\frac{E_{E, 0}\left[Y_{i t}\right]-Y_{i}^{-}}{Y_{i}^{+}-Y_{i}^{-}}\right)^{1-\sigma}-1}{(1-\sigma)(1-\beta)}+\frac{(1-\sigma)(1-\beta) \text { DirectLCost }}{(1-\sigma)(1-\beta)} \\
& =\frac{\left(\frac{E_{F, 0}\left[Y_{i t}\right]-Y_{i}^{-}}{Y_{i}^{+}-Y_{i}^{-}}\right)^{1-\sigma}-\left(\frac{E_{E, 0}\left[Y_{i t}\right]-Y_{i}^{-}}{Y_{i}^{+}-Y_{i}^{-}}\right)^{1-\sigma}}{(1-\sigma)(1-\beta)}+\frac{(1-\sigma)(1-\beta) \text { DirectLCost }}{(1-\sigma)(1-\beta)} .
\end{aligned}
$$

The following propositions are equivalent:

$$
\begin{gathered}
E_{0}\left(U_{F}\right)-E_{0}\left(U_{E}\right)>0 \\
\Longleftrightarrow \quad \frac{\left(\frac{E_{F, 0}\left[Y_{i t}\right]-Y_{i}^{-}}{Y_{i}^{+}-Y_{i}^{-}}\right)^{1-\sigma}-\left(\frac{E_{E, 0}\left[Y_{i t}\right]-Y_{i}^{-}}{Y_{i}^{+}-Y_{i}^{-}}\right)^{1-\sigma}}{(1-\sigma)(1-\beta)}+\frac{(1-\sigma)(1-\beta) \text { DirectLCost }}{(1-\sigma)(1-\beta)}>0 \\
\Longleftrightarrow(1-\sigma)(1-\beta) \text { DirectLCost }>\left(\frac{E_{E, 0}\left[Y_{i t}\right]-Y_{i}^{-}}{Y_{i}^{+}-Y_{i}^{-}}\right)^{1-\sigma}-\left(\frac{E_{F, 0}\left[Y_{i}\right]-Y_{i}^{-}}{Y_{i}^{+}-Y_{i}^{-}}\right)^{1-\sigma} .
\end{gathered}
$$

We can conclude that, if

$(1-\sigma)(1-\beta)$ DirectLCost $>\left(\frac{E_{E, 0}\left[Y_{i t}\right]-Y_{i}^{-}}{Y_{i}^{+}-Y_{i}^{-}}\right)^{1-\sigma}-\left(\frac{E_{F, 0}\left[Y_{i}\right]-Y_{i}^{-}}{Y_{i}^{+}-Y_{i}^{-}}\right)^{1-\sigma}$, then the expected utility of moving to the French region will be greater than the expected utility of moving to the English region, (i.e. $E_{0}\left(U_{F}\right)>E_{0}\left(U_{E}\right)$ ), and, therefore, agents will choose to move to the French region.

If additional to that, $\left(\frac{E_{E, 0}\left[Y_{i t}\right]-Y_{i}^{-}}{Y_{i}^{+}-Y_{i}^{-}}\right)^{1-\sigma}-\left(\frac{E_{F, 0}\left[Y_{i}\right]-Y_{i}^{-}}{Y_{i}^{+}-Y_{i}^{-}}\right)^{1-\sigma}>0$, since the function $f(x)=x^{1-\sigma}$ is an increasing function of $x$ for all $x \in \mathbb{R}$, then $E_{E, 0}\left[Y_{i t}\right]$ will be greater than $E_{F, 0}\left[Y_{i t}\right]$ and consequently,

$E_{E, 0}\left[H_{E i t}\right]-E_{F, 0}\left[H_{F i t}\right]=\frac{E_{E, 0}\left[Y_{i t}\right]-Y_{i}^{-}}{Y_{i}^{+}-Y_{i}^{-}}-\frac{E_{F, 0}\left[Y_{i t}\right]-Y_{i}^{-}}{Y_{i}^{+}-Y_{i}^{-}}$will be greater than zero. This means that the expected health condition for immigrants in the region in which French is the official language will be lower, compared to the alternative.

\subsection{Life satisfaction and health outcomes}

In this subsection, we use life satisfaction as a proxy for the distance between the observed income and the minimum income. We then analyze the effect of life satisfaction on several health measures. Table 3 shows the estimates of life satisfaction on several self-assessed health perceptions and subjective well-being indicators. Using different specifications, we show that life satisfaction has a statistically significant impact on these measures. For example, as life satisfaction improves, so does health (general, mental, and oral). A better life satisfaction is also associated with a decrease in chronic diseases (hypertension, asthma, diabetes, heart disease and cancer) and risky behavior 
(binge drinking and smoking). Finally, we observe that well-being and health indicators continue to worsen significantly for immigrants in Quebec, compared to their counterparts in the rest of Canada and Canadian-born individuals.

\section{Discussion}

Our model suggests that public policies that can reduce the fixed cost associated with the language barrier may improve health conditions for immigrants and reduce health disparities between regions. Such programs may include second language training.

Our econometric analysis also suggest that life satisfaction is associated with health variables, which supports the proposition that programs improving life satisfaction may lead to better health for immigrants. Other programs are those that improve the participation of immigrants in the labor market (Boudarbat \& Connolly (2013); Boudarbat \& Boulet (2015a) ${ }^{3}$; Boulet \& Boudarbat $\left.(2015 b)^{4}\right)$, programs that encourage social connections between immigrants and non-immigrants and programs that promote the culture of immigrants.

Conventional macroeconomic policies to increase overall economic activity may help, but may not be enough to reduce health inequalities, especially during recessions ${ }^{5}$. Improving education may help, but may not be sufficient. In fact, immigrants are selected, in part, based on their level of schooling and the demand for the type of job they are qualified to do.

\section{Conclusion}

There is little empirical literature analysing the disparities between health variables among immigrants in a given country. In our knowledge, no theoretical analysis has been done to analyse the health disparities for immigrants between two regions in a given country, where regions differs in terms of official languages and income.

The first econometric analysis of this paper compares health and well-being indicators among immigrants in Quebec, immigrants in the rest of Canada and Canadian-born individuals. Data used in our analysis are large micro-data from the Canadian Community Health Survey conducted by Statistics Canada. After controlling for a large number of relevant variables, our results show that well-being and health indicators worsen significantly for immigrants in Quebec, compared to their counterparts in the rest of Canada and Canadian-born individuals. The difference is greatest for mental health and life satisfaction.

\footnotetext{
${ }^{3}$ Data used by Boulet \& Boudarbat (2015a) come from the Quebec Survey on Working and Employment Conditions and Occupational Health and Safety (EQCOTESST).

${ }^{4}$ Boulet \& Boudarbat (2015b) used the Canadian National Graduates Survey (NGS) in their study.

${ }^{5}$ For a theoretical framework on the difficulties of improving economic activity during a recession, see Mao Takongmo (2017a); for empirical evidence, see Mao Takongmo (2017b).
} 
Table 3: Life satisfaction

\begin{tabular}{|c|c|c|c|c|c|c|c|c|c|c|}
\hline \multirow[b]{2}{*}{ Variables } & \multirow{2}{*}{$\begin{array}{c}(1) \\
\text { Life satisfaction }\end{array}$} & \multicolumn{4}{|c|}{ (2) } & \multirow{2}{*}{$\begin{array}{c}(3) \\
\text { Life satisfaction }\end{array}$} & \multicolumn{4}{|c|}{ (4) } \\
\hline & & Life satisfaction & Que & Imm & Que*Imm & & Life satisfaction & Que & Imm & Que*Imm \\
\hline Overall health $(+)$ & $\begin{array}{c}0.565^{* * *} \\
(0.007)\end{array}$ & $\begin{array}{c}0.565^{* * *} \\
(0.007)\end{array}$ & $\begin{array}{c}0.045^{* * *} \\
(0.015)\end{array}$ & $\begin{array}{c}0.017 \\
(0.019)\end{array}$ & $\begin{array}{l}-0.016 \\
(0.018)\end{array}$ & $\begin{array}{c}0.556^{* * *} \\
(0.008)\end{array}$ & $\begin{array}{c}0.557^{* * *} \\
(0.007)\end{array}$ & $\begin{array}{c}0.0602^{* *} \\
(0.025)\end{array}$ & $\begin{array}{l}0.028^{* *} \\
(0.012)\end{array}$ & $\begin{array}{c}-0.082^{* * *} \\
(0.015)\end{array}$ \\
\hline Mental health $(+)$ & $\begin{array}{c}0.761^{* * *} \\
(0.009)\end{array}$ & $\begin{array}{c}0.764^{* * *} \\
(0.007)\end{array}$ & $\begin{array}{c}0.102^{* * *} \\
(0.023)\end{array}$ & $\begin{array}{c}0.075^{* * *} \\
(0.013)\end{array}$ & $\begin{array}{c}-0.042^{* * *} \\
(0.013)\end{array}$ & $\begin{array}{c}0.748^{* * *} \\
(0.007)\end{array}$ & $\begin{array}{c}0.753^{* * *} \\
(0.007)\end{array}$ & $\begin{array}{c}0.120^{* * *} \\
(0.027)\end{array}$ & $\begin{array}{c}0.084^{* * *} \\
(0.009)\end{array}$ & $\begin{array}{c}-0.073^{* * *} \\
(0.012)\end{array}$ \\
\hline Oral health $(+)$ & $\begin{array}{c}0.346^{* * *} \\
(0.008)\end{array}$ & $\begin{array}{c}0.337^{* * *} \\
(0.008)\end{array}$ & $\begin{array}{c}0.066^{* *} \\
(0.027)\end{array}$ & $\begin{array}{c}-0.149^{* * *} \\
(0.032)\end{array}$ & $\begin{array}{c}-0.138^{* * *} \\
(0.031)\end{array}$ & $\begin{array}{c}0.324^{* * *} \\
(0.008)\end{array}$ & $\begin{array}{c}0.315^{* * *} \\
(0.007)\end{array}$ & $\begin{array}{l}0.025^{*} \\
(0.013)\end{array}$ & $\begin{array}{c}-0.140^{* * *} \\
(0.029)\end{array}$ & $\begin{array}{c}-0.169^{* * *} \\
(0.028)\end{array}$ \\
\hline Hypertension (-) & $\begin{array}{c}-0.025^{* * *} \\
(0.001)\end{array}$ & $\begin{array}{c}-0.025^{* * *} \\
(0.001)\end{array}$ & $\begin{array}{c}0.001 \\
(0.004)\end{array}$ & $\begin{array}{c}0.006 \\
(0.005)\end{array}$ & $\begin{array}{c}-0.027^{* * *} \\
(0.004)\end{array}$ & $\begin{array}{c}-0.021 * * * \\
(0.001)\end{array}$ & $\begin{array}{c}-0.022^{* * *} \\
(0.001)\end{array}$ & $\begin{array}{l}-0.005 \\
(0.004)\end{array}$ & $\begin{array}{l}-0.002 \\
(0.004)\end{array}$ & $\begin{array}{c}-0.010^{* * *} \\
(0.004)\end{array}$ \\
\hline Asthma (-) & $\begin{array}{c}-0.015^{* * *} \\
(0.001)\end{array}$ & $\begin{array}{c}-0.017 * * * \\
(0.001)\end{array}$ & $\begin{array}{l}-0.004 \\
(0.002)\end{array}$ & $\begin{array}{c}-0.045^{* * *} \\
(0.003)\end{array}$ & $\begin{array}{c}0.002 \\
(0.003)\end{array}$ & $\begin{array}{c}-0.015^{* * *} \\
(0.001)\end{array}$ & $\begin{array}{c}-0.016^{* * *} \\
(0.001)\end{array}$ & $\begin{array}{l}-0.006 \\
(0.004)\end{array}$ & $\begin{array}{c}-0.042^{* * *} \\
(0.003)\end{array}$ & $\begin{array}{c}0.001 \\
(0.004)\end{array}$ \\
\hline Diabete (-) & $\begin{array}{c}-0.014^{* * *} \\
(0.001)\end{array}$ & $\begin{array}{c}-0.014^{* * *} \\
(0.001)\end{array}$ & $\begin{array}{c}0.000 \\
(0.002)\end{array}$ & $\begin{array}{c}0.009^{* *} \\
(0.004)\end{array}$ & $\begin{array}{l}-0.006^{*} \\
(0.003)\end{array}$ & $\begin{array}{c}-0.012^{* * *} \\
(0.001)\end{array}$ & $\begin{array}{c}-0.011^{* * *} \\
(0.001)\end{array}$ & $\begin{array}{l}-0.002 \\
(0.002)\end{array}$ & $\begin{array}{l}0.006^{*} \\
(0.003)\end{array}$ & $\begin{array}{c}0.001 \\
(0.003)\end{array}$ \\
\hline Heart disease (-) & $\begin{array}{c}-0.010^{* * *} \\
(0.001)\end{array}$ & $\begin{array}{c}-0.010^{* * *} \\
(0.001)\end{array}$ & $\begin{array}{c}0.007 * * * \\
(0.001)\end{array}$ & $\begin{array}{c}-0.003^{*} \\
(0.002)\end{array}$ & $\begin{array}{c}-0.005^{* * *} \\
(0.002)\end{array}$ & $\begin{array}{c}-0.009 * * * \\
(0.001)\end{array}$ & $\begin{array}{c}-0.009 * * * \\
(0.001)\end{array}$ & $\begin{array}{c}0.003^{* *} \\
(0.001)\end{array}$ & $\begin{array}{c}-0.004^{* *} \\
(0.002)\end{array}$ & $\begin{array}{l}-0.002 \\
(0.002)\end{array}$ \\
\hline Cancer (-) & $\begin{array}{c}-0.003^{* * *} \\
(0.001)\end{array}$ & $\begin{array}{c}-0.003^{* * *} \\
(0.000)\end{array}$ & $\begin{array}{c}0.000 \\
(0.001)\end{array}$ & $\begin{array}{c}-0.002^{* * *} \\
(0.001)\end{array}$ & $\begin{array}{c}-0.003^{* * *} \\
(0.000)\end{array}$ & $\begin{array}{c}-0.002^{* * *} \\
(0.000)\end{array}$ & $\begin{array}{c}-0.002^{* * *} \\
(0.000)\end{array}$ & $\begin{array}{c}-0.002^{*} \\
(0.001)\end{array}$ & $\begin{array}{c}-0.002^{* * *} \\
(0.001)\end{array}$ & $\begin{array}{c}-0.001^{*} \\
(0.000)\end{array}$ \\
\hline Anxiety disorders (-) & $\begin{array}{c}-0.036^{* * *} \\
(0.001)\end{array}$ & $\begin{array}{c}-0.037^{* * *} \\
(0.001)\end{array}$ & $\begin{array}{c}-0.005^{* *} \\
(0.002)\end{array}$ & $\begin{array}{c}-0.034^{* * *} \\
(0.003)\end{array}$ & $\begin{array}{c}0.008^{* * *} \\
(0.003)\end{array}$ & $\begin{array}{c}-0.033^{* * *} \\
(0.001)\end{array}$ & $\begin{array}{c}-0.034^{* * *} \\
(0.001)\end{array}$ & $\begin{array}{c}-0.009^{* * *} \\
(0.002)\end{array}$ & $\begin{array}{c}-0.0298^{* * *} \\
(0.002)\end{array}$ & $\begin{array}{c}0.009^{* * *} \\
(0.003)\end{array}$ \\
\hline Mood disorders (-) & $\begin{array}{c}-0.055^{* * *} \\
(0.002)\end{array}$ & $\begin{array}{c}-0.056^{* * *} \\
(0.002)\end{array}$ & $\begin{array}{c}-0.023^{* * *} \\
(0.002)\end{array}$ & $\begin{array}{c}-0.035^{* * *} \\
(0.003)\end{array}$ & $\begin{array}{c}0.011^{* * *} \\
(0.003)\end{array}$ & $\begin{array}{c}-0.051^{* * *} \\
(0.002)\end{array}$ & $\begin{array}{c}-0.052^{* * *} \\
(0.002)\end{array}$ & $\begin{array}{c}-0.024^{* * *} \\
(0.001)\end{array}$ & $\begin{array}{c}-0.0321 * * * \\
(0.002)\end{array}$ & $\begin{array}{c}0.013^{* * *} \\
(0.002)\end{array}$ \\
\hline Regular medical doctor $(+)$ & $\begin{array}{c}0.016^{* * *} \\
(0.002)\end{array}$ & $\begin{array}{c}0.018^{* * *} \\
(0.001)\end{array}$ & $\begin{array}{c}-0.153^{* * *} \\
(0.021)\end{array}$ & $\begin{array}{c}0.009 \\
(0.006)\end{array}$ & $\begin{array}{c}-0.116^{* * *} \\
(0.016)\end{array}$ & $\begin{array}{c}0.013^{* * *} \\
(0.001)\end{array}$ & $\begin{array}{c}0.011^{* * *} \\
(0.002)\end{array}$ & $\begin{array}{c}-0.157^{* * *} \\
(0.012)\end{array}$ & $\begin{array}{c}-0.013^{* *} \\
(0.006)\end{array}$ & $\begin{array}{c}-0.082^{* * *} \\
(0.011)\end{array}$ \\
\hline Drinking- type of drinking (-) & $\begin{array}{c}0.138^{* * *} \\
(0.011)\end{array}$ & $\begin{array}{c}0.112^{* * *} \\
(0.007)\end{array}$ & $\begin{array}{c}0.178^{* * *} \\
(0.030)\end{array}$ & $\begin{array}{c}-0.572^{* * *} \\
(0.041)\end{array}$ & $\begin{array}{c}0.052 \\
(0.044)\end{array}$ & $\begin{array}{c}0.127^{* * *} \\
(0.008)\end{array}$ & $\begin{array}{c}0.103^{* * *} \\
(0.004)\end{array}$ & $\begin{array}{c}0.139^{* * *} \\
(0.041)\end{array}$ & $\begin{array}{c}-0.541 * * * \\
(0.041)\end{array}$ & $\begin{array}{l}-0.026 \\
(0.043)\end{array}$ \\
\hline Drinking- binge drinking (-) & $\begin{array}{c}-0.016^{* * *} \\
(0.003)\end{array}$ & $\begin{array}{c}-0.021 * * * \\
(0.002)\end{array}$ & $\begin{array}{c}-0.028^{* * *} \\
(0.005)\end{array}$ & $\begin{array}{c}-0.140^{* * *} \\
(0.004)\end{array}$ & $\begin{array}{c}0.036^{* * *} \\
(0.004)\end{array}$ & $\begin{array}{l}-0.002 \\
(0.003)\end{array}$ & $\begin{array}{c}-0.006^{* * *} \\
(0.002)\end{array}$ & $\begin{array}{c}-0.017 * * * \\
(0.006)\end{array}$ & $\begin{array}{c}-0.119 * * * \\
(0.004)\end{array}$ & $\begin{array}{c}0.013^{* * *} \\
(0.003)\end{array}$ \\
\hline Smoking (-) & $\begin{array}{c}-0.103^{* * *} \\
(0.007)\end{array}$ & $\begin{array}{c}-0.135^{* * *} \\
(0.007)\end{array}$ & $\begin{array}{c}0.137^{* * *} \\
(0.014)\end{array}$ & $\begin{array}{c}-0.565^{* * *} \\
(0.015)\end{array}$ & $\begin{array}{c}0.036^{* *} \\
(0.015)\end{array}$ & $\begin{array}{c}-0.075^{* * *} \\
(0.008)\end{array}$ & $\begin{array}{c}-0.104^{* * *} \\
(0.008)\end{array}$ & $\begin{array}{c}0.101^{* * *} \\
(0.019)\end{array}$ & $\begin{array}{c}-0.550^{* * *} \\
(0.005)\end{array}$ & $\begin{array}{c}0.065^{* * *} \\
(0.001)\end{array}$ \\
\hline $\begin{array}{l}\text { Fruit and vegetable } \\
\text { consumption }(+)\end{array}$ & $\begin{array}{c}0.408^{* * *} \\
(0.017)\end{array}$ & $\begin{array}{c}0.407^{* * *} \\
(0.011)\end{array}$ & $\begin{array}{c}0.566^{* * *} \\
(0.061)\end{array}$ & $\begin{array}{c}0.191^{* *} \\
(0.069)\end{array}$ & $\begin{array}{c}-0.351^{* * *} \\
(0.070)\end{array}$ & $\begin{array}{c}0.324^{* * *} \\
(0.010)\end{array}$ & $\begin{array}{c}0.332^{* * *} \\
(0.011)\end{array}$ & $\begin{array}{c}0.308^{* * *} \\
(0.054)\end{array}$ & $\begin{array}{c}0.185^{* *} \\
(0.066)\end{array}$ & $\begin{array}{c}-0.352^{* * *} \\
(0.066)\end{array}$ \\
\hline Obesity and overweight (-) & $\begin{array}{c}-0.017^{* * *} \\
(0.002)\end{array}$ & $\begin{array}{c}-0.021^{* * *} \\
(0.002)\end{array}$ & $\begin{array}{c}-0.060^{* * *} \\
(0.014)\end{array}$ & $\begin{array}{c}-0.111^{* * *} \\
(0.019)\end{array}$ & $\begin{array}{c}0.090^{* * *} \\
(0.019)\end{array}$ & $\begin{array}{c}-0.015^{* * *} \\
(0.003)\end{array}$ & $\begin{array}{c}-0.020^{* * *} \\
(0.002)\end{array}$ & $\begin{array}{c}-0.055^{* * *} \\
(0.012)\end{array}$ & $\begin{array}{c}-0.124^{* * *} \\
(0.018)\end{array}$ & $\begin{array}{c}0.097^{* * *} \\
(0.016)\end{array}$ \\
\hline Physical activity $(+)$ & $\begin{array}{c}0.066^{* * *} \\
(0.004)\end{array}$ & $\begin{array}{c}0.064^{* * *} \\
(0.003)\end{array}$ & $\begin{array}{c}-0.085^{* * *} \\
(0.009)\end{array}$ & $\begin{array}{c}-0.075^{* * *} \\
(0.017)\end{array}$ & $\begin{array}{c}0.044^{* *} \\
(0.019)\end{array}$ & $\begin{array}{c}0.067^{* * *} \\
(0.002)\end{array}$ & $\begin{array}{c}0.064^{* * *} \\
(0.002)\end{array}$ & $\begin{array}{c}-0.098^{* * *} \\
(0.012)\end{array}$ & $\begin{array}{c}-0.063^{* * *} \\
(0.017)\end{array}$ & $\begin{array}{l}0.033^{*} \\
(0.019)\end{array}$ \\
\hline Home ownership $(+)$ & $\begin{array}{c}0.084^{* * *} \\
(0.005)\end{array}$ & $\begin{array}{c}0.082^{* * *} \\
(0.005)\end{array}$ & $\begin{array}{c}-0.085^{* * *} \\
(0.014)\end{array}$ & $\begin{array}{c}-0.061^{* * *} \\
(0.013)\end{array}$ & $\begin{array}{c}-0.135^{* * *} \\
(0.017)\end{array}$ & $\begin{array}{c}0.062^{* * *} \\
(0.004)\end{array}$ & $\begin{array}{c}0.055^{* * *} \\
(0.002)\end{array}$ & $\begin{array}{c}-0.074^{* * *} \\
(0.013)\end{array}$ & $\begin{array}{c}-0.121^{* * *} \\
(0.012)\end{array}$ & $\begin{array}{c}-0.096^{* * *} \\
(0.016)\end{array}$ \\
\hline $\begin{array}{l}\text { Control variables } \\
\text { Que; Imm; Imm*que } \\
\text { Personal \& family } \\
\text { Year fixed effects }\end{array}$ & $\begin{array}{l}\text { No } \\
\text { No } \\
\text { Yes }\end{array}$ & & $\begin{array}{l}\text { Yes } \\
\text { No } \\
\text { Yes }\end{array}$ & & & $\begin{array}{l}\text { No } \\
\text { Yes } \\
\text { Yes }\end{array}$ & & $\begin{array}{l}\text { Yes } \\
\text { Yes } \\
\text { Yes }\end{array}$ & & \\
\hline
\end{tabular}

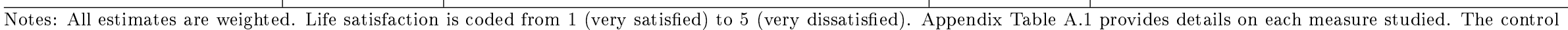
variables in each of the specifications are those shown in table A.2. Standard errors are reported in parentheses. ***: significant at $1 \% ; * *$ : significant at $5 \% ; *$ : significant at $10 \%$ 
Additional econometric analysis also show that life satisfaction is statistically and significantly associated with other health variables.

The paper also proposes a simple structural model to assess a possible channel that can lead to observed health gaps for immigrants between regions, despite the universal health system. The proposed structural model suggest that, if agents are short-sighted regarding their future health conditions when taking their decisions, and if the fixed cost associated with the language barrier is sufficiently large (compared to the difference in expected income between regions), then agents will move to the region with an official language that is similar to their native language, and their expected health condition will be low. 


\section{Bibliography}

[1] Beiser, M. (2005). The health of immigrants and refugees in Canada. Canadian Journal of Public Health/Revue Canadienne de Santé Publique, S30-S44.

[2] Boudarbat, B., \& Connolly, M. (2013). Évolution de l'accès à l'emploi et des conditions de travail des immigrants au Québec, en Ontario et en Colombie - Britannique entre 2006 et 2012 (No. 2013s-28). CIRANO.

[3] Boulet, M., \& Boudarbat, B. (2015a). Qualité de l'emploi et santé mentale des travailleurs au Quï¿œbec: une comparaison entre les immigrants et les natifs. Canadian Public Policy, 41(2), S53-S60.

[4] Boulet, M., \& Boudarbat, B. (2015b). The economic performance of immigrants with Canadian education. Regional and Sectoral Economic Studies, 15(2), 23-40.

[5] Bradshaw, J., Hoelscher, P., \& Richardson, D. (2007). An index of child well-being in the European Union. Social Indicators Research, 80(1), 133-177.

[6] Canadian Institute for Health Information (CIHI). (2016). How Canada Compares: Results From The Commonwealth Fund 2015 International Health Policy Survey of Primary Care Physicians. Retrieved 02/12/2017 from https://www.cihi.ca/en/health-systemperformance/performance-reporting/international/commonwealth-fund-survey-2015

[7] De Maio, F. G., \& Kemp, E. (2010). The deterioration of health status among immigrants to Canada. Global Public Health, 5(5), 462-478.

[8] Flegel, K., MacDonald, N., \& Hï¡œbert, P. C. (2011). Binge drinking: all too prevalent and hazardous. CMAJ, 183(4), 411.

[9] Gee, E. M. T., Kobayashi, K. M., \& Prus, S. G. (2004). Examining the healthy immigrant effect in mid-to later life: findings from the Canadian Community Health Survey. Canadian Journal on Aging/La Revue canadienne du vieillissement, 23(5), S55-S63.

[10] Government of Canada. (1984). Canada Health Act. Retrieved 02/12/2017 from http://lawslois.justice.gc.ca/eng/acts/C-6/page-1.html

[11] Government of Canada. (2002). Immigration and Refugee Protection Regulations (SOR/2002227). Retrieved 10/06/2017 from http://laws-lois.justice.gc.ca/eng/regulations/SOR-2002227/20060322/P1TT3xt3.html

[12] Government of Canada. (2017). Medical exam for permanent residents. Retrieved 10/06/2017 from http://www.cic.gc.ca/english/information/medical/medexams-perm.asp 
[13] Mao Takongmo, C. O. (2017a). Government-spending multipliers and the zero lower bound in an open economy. Review of International Economics, 25 (5), 1046-1077.

[14] Mao Takongmo, C. O. (2017b). Government spending, GDP and exchange rate in Zero Lower Bound: measuring causality at multiple horizons. MPRA Working Paper No. 79703

[15] Statistics Canada. (2005). Canadian Community Health Survey (CCHS)- Main file.

[16] Statistics Canada. (2011). Immigration and Ethnocultural Diversity in Canada. National Household survey, 2001, Catalogue no. 99-010-X2011001

[17] UNICEF Office of Research. (2013). Child well-being in rich countries: A comparative overview. Innocenti Report Card 11. Florence: UNICEF Office of Research.

[18] Wang, L., \& Palacios, E. L. (2017). The Social and Spatial Patterning of Life Stress Among Immigrants in Canada. Journal of Immigrant and Minority Health, 19(3), 665-673. 


\section{APPENDIX}

Table A.1: Well-Being and Health Measures (CCHS)

\begin{tabular}{|c|c|}
\hline $\begin{array}{l}\text { Overall health } \\
\text { (Range: } 1-5)\end{array}$ & $\begin{array}{l}\text { In general, would you say your health is: } \\
\text { 1) poor } \\
\text { 2) fair } \\
\text { 3) good } \\
\text { 4) very good } \\
\text { 5) excellent }\end{array}$ \\
\hline $\begin{array}{l}\text { Mental health } \\
\text { (Range: } 1-5)\end{array}$ & $\begin{array}{l}\text { In general, would you say your mental health is: } \\
\text { 1) poor } \\
\text { 2) fair } \\
\text { 3) good } \\
\text { 4) very good } \\
\text { 5) excellent }\end{array}$ \\
\hline $\begin{array}{l}\text { Life satisfaction } \\
\text { (Range: } 1-5 \text { ) }\end{array}$ & $\begin{array}{l}\text { How satisfied are you with your life in general: } \\
\text { 1) very dissatisfied } \\
\text { 2) dissatisfied } \\
\text { 3) neither satisfied nor dissatisfied } \\
\text { 4) satisfied } \\
\text { 5) very satisfied }\end{array}$ \\
\hline $\begin{array}{l}\text { Oral health } \\
\text { (Range: } 1-5)\end{array}$ & $\begin{array}{l}\text { In general, would you say the health of your teeth and mouth is: } \\
\text { 1) poor } \\
\text { 2) fair } \\
\text { 3) good } \\
\text { 4) very good } \\
\text { 5) excellent }\end{array}$ \\
\hline $\begin{array}{l}\text { Drinking- Type of drinking } \\
\text { (Range: } 1-3 \text { ) }\end{array}$ & $\begin{array}{l}\text { During the past } 12 \text { months, have you had beer, wine, liquor or any other alcoholic beverage?: } \\
\text { 1) Not at all } \\
\text { 2) Occasionally (less than once a month) } \\
\text { 3) Regularly (once a month to every day) }\end{array}$ \\
\hline $\begin{array}{l}\text { Smoking } \\
\text { (Range: } 1-3)\end{array}$ & $\begin{array}{l}\text { Type of smoker: } \\
\text { 1) Not at all } \\
\text { 2) Occasionally (less than once a month) } \\
\text { 3) Regularly (once a month to every day) }\end{array}$ \\
\hline Daily consumption & $\begin{array}{l}\text { Total fruits and vegetables: } \\
\text { The CCHS measures the number of times (frequency), not the amount consumed. }\end{array}$ \\
\hline
\end{tabular}


Table A.2: Summary Statistics

\begin{tabular}{|c|c|c|c|c|c|c|c|}
\hline & \multicolumn{2}{|c|}{ Quebec } & \multirow{3}{*}{$\begin{array}{c}(1) \\
\text { Difference } \\
\text { Imm-Non imm }\end{array}$} & \multicolumn{2}{|c|}{ Rest of Canada } & \multirow{3}{*}{$\begin{array}{c}(2) \\
\text { Difference } \\
\text { Imm-Non imm }\end{array}$} & \multirow{3}{*}{$\begin{array}{c}(1)-(2) \\
\text { Prob }>\text { Chi2 }\end{array}$} \\
\hline & Immigrant & Non-immigrant & & Immigrant & Non-immigrant & & \\
\hline & & & & & & & \\
\hline \multicolumn{8}{|l|}{ Sex } \\
\hline Male & $0.528(0.499)$ & $0.497(0.500)$ & $0.030(0.012)^{* *}$ & $0.486(0.500)$ & $0.501(0.499)$ & $-0.016(0.005)^{* * *}$ & 0.000 \\
\hline \multicolumn{8}{|l|}{ Age } \\
\hline $20-24$ & $0.080(0.272)$ & $0.121(0.326)$ & $-0.040(0.007)^{* * *}$ & $0.086(0.280)$ & $0.134(0.340)$ & $-0.048(0.003)^{* * *}$ & 0.309 \\
\hline $25-29$ & $0.117(0.321)$ & $0.117(0.321)$ & $-0.001(0.007)$ & $0.095(0.293)$ & $0.127(0.332)$ & $-0.031(0.003)^{* * *}$ & 0.000 \\
\hline $30-34$ & $0.161(0.367)$ & $0.109(0.312)$ & $0.052(0.008)^{* * *}$ & $0.109(0.312)$ & $0.114(0.318)$ & $-0.005(0.003)^{* *}$ & 0.000 \\
\hline $35-39$ & $0.162(0.368)$ & $0.112(0.315)$ & $0.050(0.008)^{* * *}$ & $0.142(0.349)$ & $0.122(0.328)$ & $0.020(0.003) * * *$ & 0.000 \\
\hline $40-44$ & $0.144(0.352)$ & $0.138(0.345)$ & $0.006(0.008)$ & $0.163(0.369)$ & $0.141(0.347)$ & $0.023(0.004) * * *$ & 0.067 \\
\hline $45-49$ & $0.119(0.324)$ & $0.139(0.346)$ & $-0.020(0.009)^{* *}$ & $0.142(0.349)$ & $0.136(0.343)$ & $0.006(0.004) *$ & 0.006 \\
\hline $50-54$ & $0.109(0.312)$ & $0.143(0.350)$ & $-0.034(0.008)^{* * *}$ & $0.131(0.338)$ & $0.123(0.328)$ & $0.009(0.003)^{* * *}$ & 0.000 \\
\hline $55-59$ & $0.108(0.310)$ & $0.122(0.327)$ & $-0.014(0.008)^{*}$ & $0.131(0.337)$ & $0.103(0.304)$ & $0.027(0.003)^{* * *}$ & 0.000 \\
\hline \multicolumn{8}{|l|}{ Household size } \\
\hline 1 person & $0.131(0.337)$ & $0.146(0.349)$ & $-0.011(0.006)^{*}$ & $0.081(0.272)$ & $0.110(0.313)$ & $-0.0290 .002)^{* * *}$ & 0.002 \\
\hline 2 persons & $0.248(0.432)$ & $0.333(0.471)$ & $-0.086(0.009)^{* * *}$ & $0.214(0.410)$ & $0.303(0.459)$ & $-0.089(0.003)^{* * *}$ & 0.713 \\
\hline 3 persons & $0.233(0.423)$ & $0.221(0.415)$ & $0.012(0.010)$ & $0.220(0.414)$ & $0.218(0.413)$ & $0.002(0.004)$ & 0.375 \\
\hline 4 persons & $0.230(0.421)$ & $0.211(0.408)$ & $0.019(0.011)^{*}$ & $0.270(0.444)$ & $0.241(0.427)$ & $0.029(0.005)^{* * *}$ & 0.381 \\
\hline $5+$ persons & $0.159(0.366)$ & $0.093(0.291)$ & $0.066(0.009)^{* * *}$ & $0.216(0.412)$ & $0.129(0.335)$ & $0.087(0.004)^{* * *}$ & 0.037 \\
\hline \multicolumn{8}{|c|}{ Highest level of education attained } \\
\hline Less than high school & $0.106(0.308)$ & $0.135(0.342)$ & $-0.029(0.008)^{* * *}$ & $0.090(0.286)$ & $0.097(0.296)$ & $-0.007(0.003)^{* * *}$ & 0.010 \\
\hline High school diploma & $0.108(0.310)$ & $0.136(0.343)$ & $-0.029(0.008)^{* * *}$ & $0.169(0.375)$ & $0.193(0.395)$ & $-0.024(0.004) * * *$ & 0.560 \\
\hline Some college & $0.047(0.212)$ & $0.069(0.254)$ & $-0.022(0.005)^{* * *}$ & $0.072(0.258)$ & $0.099(0.298)$ & $-0.027(0.003)^{* * *}$ & 0.409 \\
\hline Bachelor's and above & $0.739(0.244)$ & $0.659(0.474)$ & $0.080(0.011)^{* * *}$ & $0.669(0.471)$ & $0.611(0.488)$ & $0.058(0.005)^{* * *}$ & 0.064 \\
\hline \multicolumn{8}{|l|}{ Marital status } \\
\hline Married/common-law & $0.689(0.463)$ & $0.638(0.481)$ & $0.051(0.011)^{* * *}$ & $0.731(0.443)$ & $0.648(0.478)$ & $0.084(0.004)^{* * *}$ & 0.004 \\
\hline Single/never married & $0.214(0.410)$ & $0.269(0.443)$ & $-0.055(0.009)^{* * *}$ & $0.188(0.391)$ & $0.268(0.444)$ & $-0.080(0.004)^{* * *}$ & 0.011 \\
\hline Widowed/divorced/separated & $0.098(0.297)$ & $0.093(0.291)$ & $0.005(0.007)$ & $0.081(0.272)$ & $0.084(0.277)$ & $-0.004(0.002)$ & 0.266 \\
\hline \multicolumn{8}{|c|}{ Language in which the respondent can converse } \\
\hline English & $0.152(0.359)$ & $0.016(0.126)$ & $0.136(0.009)^{* * *}$ & $0.857(0.350)$ & $0.839(0.367)$ & $0.018(0.003)^{* * *}$ & 0.000 \\
\hline French & $0.245(0.430)$ & $0.486(0.500)$ & $-0.242(0.010)^{* * *}$ & $0.110(0.033)$ & $0.004(0.060)$ & $-0.003(0.000)^{* * *}$ & 0.000 \\
\hline English and French & $0.565(0.496)$ & $0.497(0.500)$ & $0.069(0.012)^{* * *}$ & $0.079(0.270)$ & $0.155(0.362)$ & $-0.076(0.003)^{* * *}$ & 0.000 \\
\hline Neither & $0.038(0.190)$ & $0.080(0.028)$ & $0.037(0.006)^{* * *}$ & $0.063(0.243)$ & $0.020(0.045)$ & $0.061(0.002)^{* * *}$ & 0.000 \\
\hline $\mathrm{N}$ & 4,599 & 53,703 & & 33,348 & 193,665 & & \\
\hline
\end{tabular}

